Fall 2016

\title{
Rediscovering Physical Collections Through the Digital Archive: The Jesuit Libraries Provenance Project
}

Kyle Roberts

Loyola University Chicago, kroberts2@luc.edu

Follow this and additional works at: https://ecommons.luc.edu/history_facpubs

Part of the Databases and Information Systems Commons, and the History Commons

\section{Recommended Citation}

Roberts, Kyle. Rediscovering Physical Collections Through the Digital Archive: The Jesuit Libraries Provenance Project. Collections: A Journal for Museum and Archives Professionals, 12, 4: 445-458, 2016. Retrieved from Loyola eCommons, History: Faculty Publications and Other Works,

This Article is brought to you for free and open access by the Faculty Publications and Other Works by Department at Loyola eCommons. It has been accepted for inclusion in History: Faculty Publications and Other Works by an authorized administrator of Loyola eCommons. For more information, please contact ecommons@luc.edu. (C) Rowman \& Littlefield Publishers, Inc. 2016 


\title{
Rediscovering Physical Collections Through the Digital Archive
}

\section{The Jesuit Libraries Provenance Project}

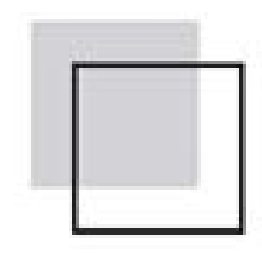

\section{Kyle B. Roberts}

\begin{abstract}
Assistant Professor of Public History and New Media and Director, Center for Textual Studies and Digital Humanities, Loyola University Chicago, Chicago, IL, kroberts2@luc.edu
\end{abstract}

Abstract Historic library collections offer a rich and underexplored resource for teaching undergraduate and graduate students about new digital approaches, methodologies, and platforms. Their scope and scale can make them difficult to analyze in their physical form, but remediated onto a digital platform, they offer valuable insights into the process of archive creation and the importance of making their content available to audiences that cannot normally access it. The Jesuit Libraries Provenance Project (JLPP) was launched by students, faculty, and library professionals in 2014 to create an online archive of marks of ownership—bookplates, stamps, inscriptions—contained within books from the original library collection of St. Ignatius College, precursor to Loyola University Chicago. The project grew out of student work for a university museum exhibition commemorating the bi-centennial of the restoration of the Society of Jesus (more commonly known as the Jesuits). Utilizing the popular social media image-sharing site Flickr, the JLPP seeks to foster a participatory community of students, scholars, collectors, and the broader public interested in the history of early and modern Catholic print and the intellectual framework and approach of 19th-century Jesuit education. Initially intended to provide students with the chance to learn how to conceptualize, plan, and build a digital archive, the JLPP has proven equally effective for teaching about digital scholarship, shared authority, and, rather unexpectedly, about the materiality of collections in the digital age

Historic library collections offer a rich and underexplored resource for teaching undergraduate and graduate students about new digital approaches, methodologies, 
and platforms. Their scope and scale can make them difficult to analyze in their physical form, but remediated onto a digital platform, they offer valuable insights into the process of archive creation and the importance of making their content available to audiences that cannot normally access it. The Jesuit Libraries Provenance Project (JLPP) was launched by students, faculty, and library professionals in 2014 to create an online archive of marks of ownership - bookplates, stamps, inscriptions - contained within books from the original library collection of St. Ignatius College, precursor to Loyola University Chicago. ${ }^{1}$ The project grew out of student work for a university museum exhibition commemorating the bicentennial of the restoration of the Society of Jesus (more commonly known as the Jesuits). ${ }^{2}$ Utilizing the popular social media image-sharing site Flickr, the JLPP seeks to foster a participatory community of students, scholars, collectors, and the broader public interested in the history of early and modern Catholic print and the intellectual framework and approach of 19th-century Jesuit education. Initially intended to provide students with the chance to learn how to conceptualize, plan, and build a digital archive, the JLPP has proven equally effective for teaching about digital scholarship, shared authority, and, rather unexpectedly, about the materiality of collections in the digital age.

Coming into Loyola as a public historian and digital humanist in Fall 2011, I felt it was important to have a research project grounded in the collections and resources of my new university or local community through which I could teach students about digital and public history. To be successful, this project had to satisfy four criteria. It had to be collaborative, bringing together students, faculty, and public historians such as archivists, librarians, and museum professionals to explore the latest digital methodologies, platforms, and theories. It had to be the subject of engaged learning opportunities-such as internships, directed studies, research seminars, and even theses and dissertations-that allowed students to integrate knowledge and theory learned in the classroom with practical applications and skill development outside of it. It had to be an open and evolving work of digital history, introducing students to a mode of scholarship predicated on publishing their findings as they went, rather than waiting for the completion of the project, and that valued reflection on process as much as final product. Lastly, my ideal project had to demonstrate the value of sharing authority. Inspired by approaches within Public History, it had to challenge students to reject traditionally held notions of who gets to interpret the past and to open authorship up to a wider range of contributors. ${ }^{3}$ It did not take long to find a promising source for such a project. The first week of my first semester at Loyola I made an appointment at the University Archives and Special Collections. In a seemingly mundane volume - a late 19th-century college library subject catalog-shared with me by the University Archivist, I found the inspiration for a project through which I could teach my students about library history, public history, Catholic history, and the digital humanities. 
Over the past decade and a half, scholars have discovered historic libraries as engaging and generative subjects for digital study. The contents of these libraries open up innumerable questions about book collection, classification, circulation, and reception. More than that, they raise the possibility of rediscovering the social, political, and cultural meanings of library communities and the environments in which these books were encountered and used. They help us think in new ways about the role of print in the production and dissemination of knowledge, the formation of communities of readers, and the construction of identity throughout the modern world. ${ }^{4}$ The data generated from historic libraries is ripe for exploration by digital humanities methods, but is not without its challenges. Past tools for library management, such as holdings catalogs and borrowing ledgers, are often difficult to analyze in their analog forms. Remediated on a digital platform, however, the holdings and borrowings of these libraries can be analyzed and visualized. Groundbreaking digital projects have revealed the potential for what can be done with these sources. City Readers offers powerful tools for visualizing the holdings and borrowing data from a late 18th-century New York City subscription library, Dissenting Academies Online: Virtual Library System has made accessible the hidden histories of reading by over six hundred early 19th-century English academy students, and What Middletown Read has provided an unprecedented view into popular reading behavior in an early 20th-century Midwestern community originally made famous by sociologists Robert and Helen Lynd. ${ }^{5}$

The bicentennial of the restoration of the Society of Jesus in 2014 provided my students and me with the opportunity to undertake a significant digital project. Over the past few decades, scholarship on the Jesuits before their global suppression by Pope Clement XIV in 1773 has burgeoned; the period after the order's restoration by Pope Pius VII in 1814, however, has been largely overlooked. ${ }^{6}$ To help rectify this lacuna, Loyola mounted a major exhibition, entitled Crossings and Dwellings: Restored Jesuits, Women Religious, American Experience 1814-2014, during the summer and fall of 2014 at the Loyola University Museum of Art. The exhibition and concluding conference explored how the United States emerged as one of the most dynamic arenas of activity for the restored order. Through the efforts of European-born Jesuits and women religious, many of them persecuted and exiled as a result of nationalistic uprisings in their natal lands, the United States became the site of important institutions of higher education in the nation's cities and the setting for expansive and ambitious missions on the frontier. ${ }^{7}$ The college and university libraries assembled by Jesuits provide a valuable lens into their participation in a transnational exchange of ideas and the challenge of devising a meaningful education for immigrant Catholics.

Loyola students designed and built a digital reconstruction of the original St. Ignatius College library catalog for the Crossings and Dwellings exhibition that made visible the intellectual framework and approach of Jesuit education. Founded after the American Civil War on the prairie on the west side of Chicago, 
St. Ignatius was part of an ambitious, coordinated effort by European-born Jesuits to establish a network of Catholic colleges throughout the upper Midwest. ${ }^{8}$ Primarily Belgian-born Jesuits first arrived in Chicago in 1857 and established a parish. Soon after they invited the Sisters of the Sacred Heart (RSCJs) and the Sisters of Charity of the Blessed Virgin Mary to open primary schools to educate children in the rapidly growing Irish Catholic immigrant neighborhood. By 1870 , they were able to build a massive six-story collegiate structure and offered a six-year course of advanced study for young men. ${ }^{9}$ Prospectuses from the college's early years tout the dramatic growth of the library's collection, which numbered over ten thousand volumes by the end of the decade. ${ }^{10}$ This is all the more impressive considering that much of the city burned down during this period. Around 1878 P.J. Van Loco, the Jesuit librarian of St Ignatius, created the subject catalog that survives today. The rapid growth of the collection, in fact, likely necessitated its creation as a finding aid. It lists approximately 5100 titles, encompassing over 8000 volumes. The catalog's arrangement in six divisionspantology, theology, legislation, philosophy, literature, and history-reflected as much the layout of library shelves as the intellectual framework of Jesuit education. Undergraduate interns digitized and transcribed the catalog before sixteen graduate students in digital humanities, history, and public history created what digital library scholars refer to as a virtual library system (VLS) as part of an Advanced Digital Methods seminar I taught in Fall 2013. ${ }^{11}$ The holdings listed in the catalog illuminated how a global pedagogical system dating back to the 16th century and encompassing not only theology and philosophy, but also the humanities, was reconciled with the needs of a rapidly commercializing city. Throughout the process, however, a nagging question remained: How many original books survived?

No one had any idea at the start of the project to create the VLS how large or small the number of surviving books might be. There were always too many other tasks to complete and not enough time to come up with an informed estimate. The conditions of the VLS' assembly, however, provided the data to track down surviving books. Rather than design a database from scratch, we decided to modify an off-the-shelf integrated library system (ILS), the software used by 21 stcentury libraries to track holdings and borrowings, allow patrons to search the collection, and provide librarians with useful tools for analyzing library activity. Students populated the ILS by matching short bibliographic references (author, title, imprint location, and date) in the 19th-century catalog with MARC records (MAchine Readable Cataloguing, the 20th-century bibliographic standard) drawn from Loyola's modern online catalog, a process known as copy-cataloguing. By the end of the Fall 2013 semester we realized that upward of a third (1750/5100) of the original titles might still survive in the university libraries' collections today. Why is this surprising? Primarily because most of the books collected by Jesuits were inexpensive mid-19th-century imprints. Mass produced on highly acidic, 


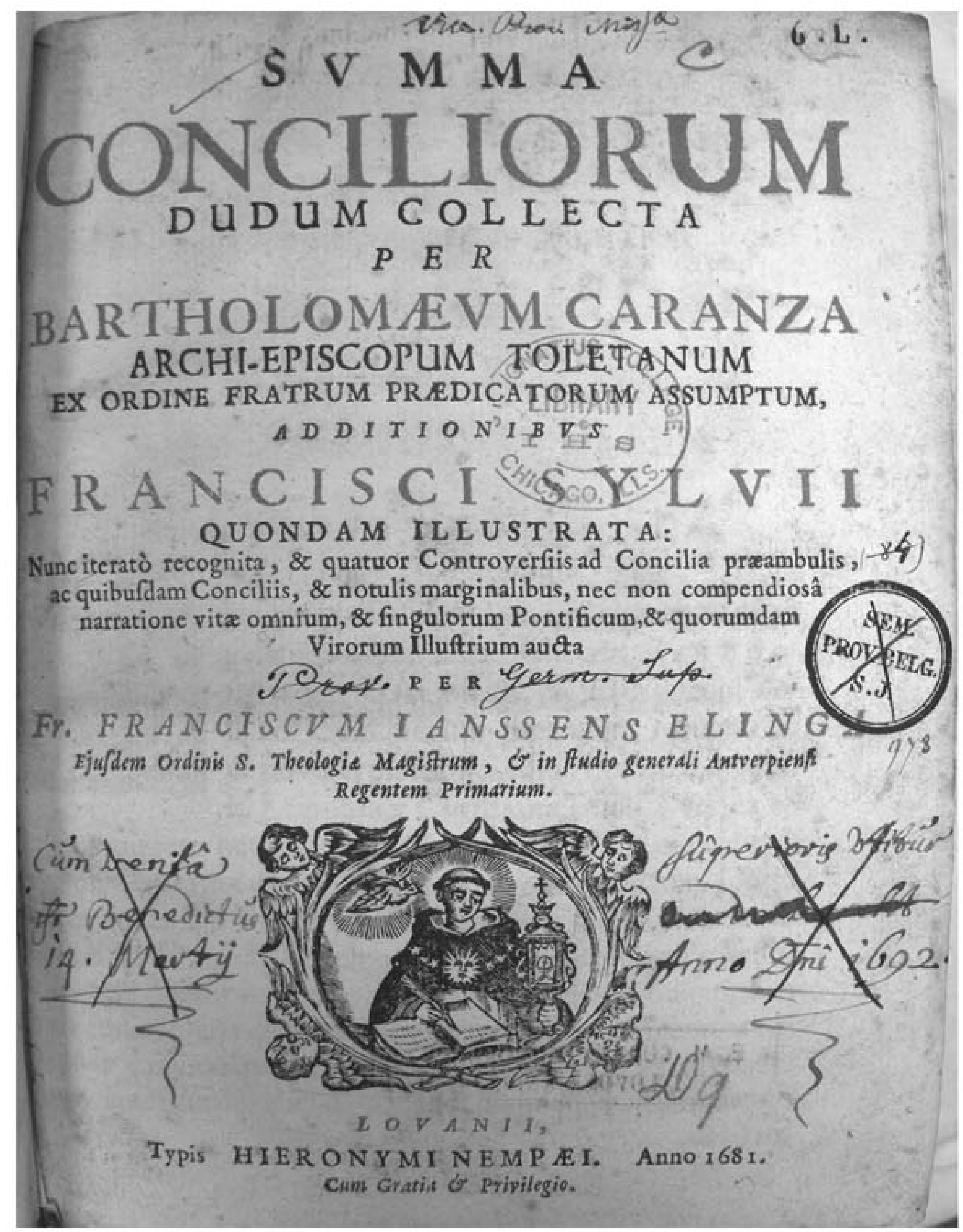

Figure 1. An illustration of the range of provenance marks in a book from the original St. Ignatius College library. Rare Books and Special Collections, Loyola University Chicago, BV710.C37 1681.

and now brittle, paper, these books after 140 plus years of hard use should have been lost or simply disintegrated.

In January 2014, several undergraduate and graduate students decided they wanted to track down books listed in the VLS as being still in Loyola's collection. They wanted to see if the material texts held any evidence that might link them to the original catalog. Armed with printouts from the VLS, they descended upon University Archives and Special Collections, the Library Storage Facility, and the stacks of Cudahy Library, the main university library. (Several students generously 

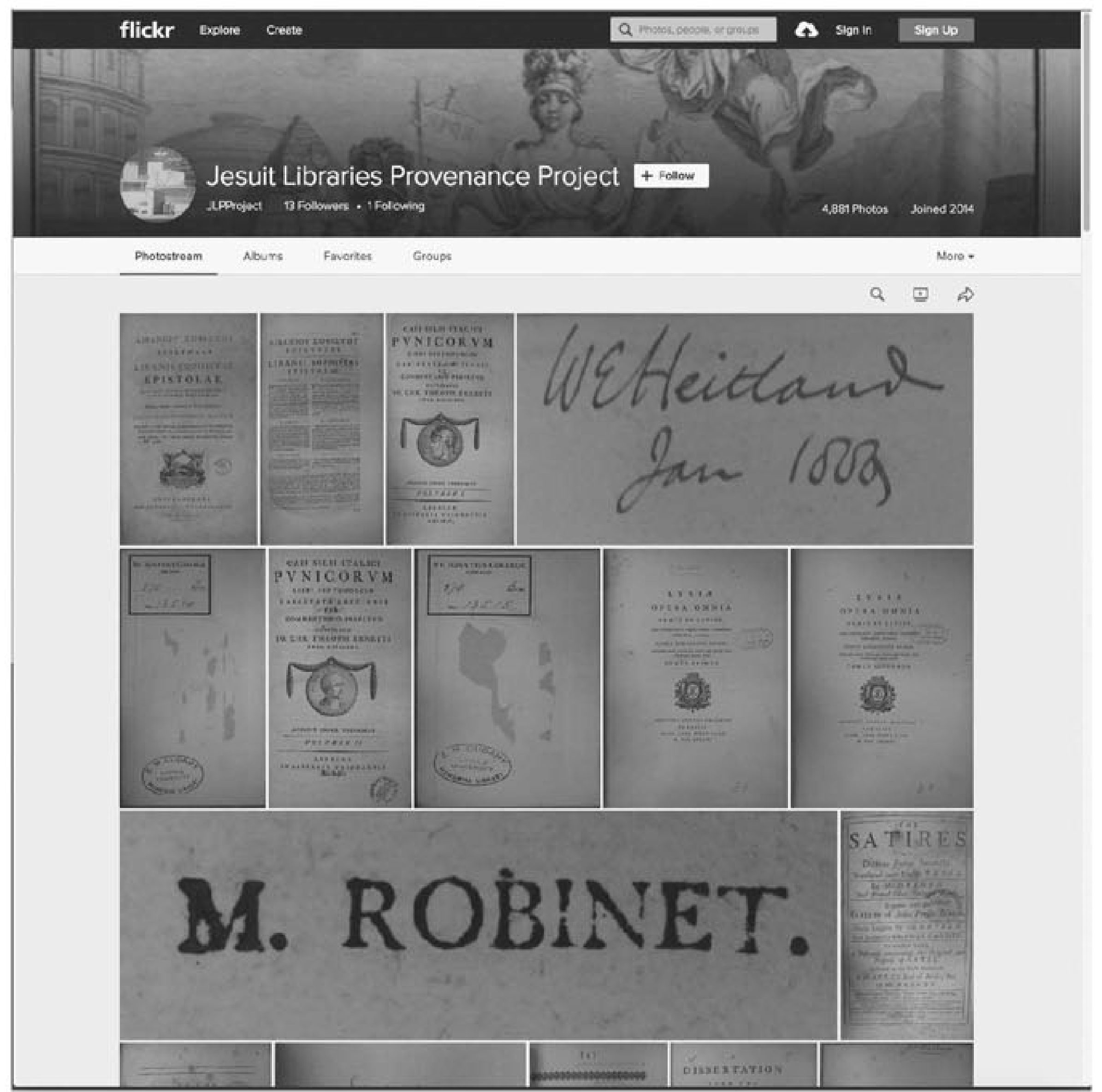

Figure 2. Photostream from the Jesuit Libraries Provenance Project Flickr site.

volunteered to track down books listed as being in the library of Loyola's Rome campus, if funds became available!) As they pulled books off the library shelves and looked inside their covers, they were surprised by what they found. Many retained evidence of previous ownership. Bookplates, inscriptions, stamps, and shelf-marks often littered the books' inside covers, flyleaves, and title pages (Figure 1). These vestiges of a book's previous life held a key to its origins and inspired a multitude of questions about the production, acquisition, and reception of early and modern Catholic print culture. While the remediated catalog in the VLS could document the books that the Jesuits acquired, surviving books had the potential to disclose where they came from and how they were used.

Inspiration for the plan of the JLPP came from similar projects undertaken by other university libraries. The Provenance Online Project (maintained 
by the Kislak Center for Special Collections, Rare Books, and Manuscripts at the University of Pennsylvania) and the Medieval Fragments Project (now defunct, at the Harry Ransom Center at the University of Texas at Austin) provided best-practice models for sharing collections and crowdsourcing identifications and transcriptions. The JLPP team decided to build off their success by using Flickr, the social media image-sharing platform, to create a visual archive of ownership marks from books in Jesuit libraries. ${ }^{12}$ Between January 2014 and December 2015, undergraduate and graduate interns tracked down and created digital images of the title pages and provenance information from thousands of surviving books. They generated extensive bibliographic metadata about each (including author, title, date, location and publisher, dimensions, and language) as well as links to Loyola's online library catalog. (Future work will include generating links to digital surrogates and to the record in the VLS once it is launched.) Images are uploaded to the Flickr photostream (https://www.flickr.com/photos/jesuitlibrariesprovenanceproject/) on a rolling basis (Figure 2). Visitors are encouraged to contribute transcriptions of inscriptions (especially ones written in messy or illegible hands), translations of phrases and passages in foreign languages, and identifications of donors. Not only does the site provide a visual index of the rich variety of works found in a late 19th-century Jesuit college library, but it also promotes conversations about the importance of print to the Catholic intellectual and spiritual heritage in general and insight into the kinds of knowledge that were valued and being circulated at a Jesuit college in particular. As of March 1, 2016, nearly 5100 images have been uploaded and the site has been viewed hundreds of thousands of times.

Learning firsthand about the importance of sharing authority has been another valuable outcome. The JLPP team could have created a stand-alone site on the university's servers, but that archive would have functioned as a silo rather than a crossroads. Flickr, we gambled, had the potential to foster a participatory community of bibliographers, academics, private collectors, alumni, and students interested in the origins of Jesuit-held books and willing to contribute their own knowledge. Creative tagging on posted images seeks to attract traffic from among the millions of Flickr users. The "Albums" feature allows for images to be grouped by subject. Organized with an eye toward particular interest areas and research questions, the JLPP's albums are arranged by division of the original catalog (i.e., theology, history), type of ownership marks (i.e., inscription, stamp, bookplate), and aspect of the book (i.e., bindings, illustrations). Ownership marks are further classified as "identified" or "unidentified" in the hopes of facilitating viewer involvement. While the number of viewers has been high, the number of contributors has been smaller, but the information provided by the latter has been invaluable.

One important outcome of the JLPP has been the opportunity undergraduate and graduate students have had to experience and reflect upon how scholarship has changed in the digital age. The JLPP team embraces an open and evolving publishing platform and began publishing images just two months into the start of the 


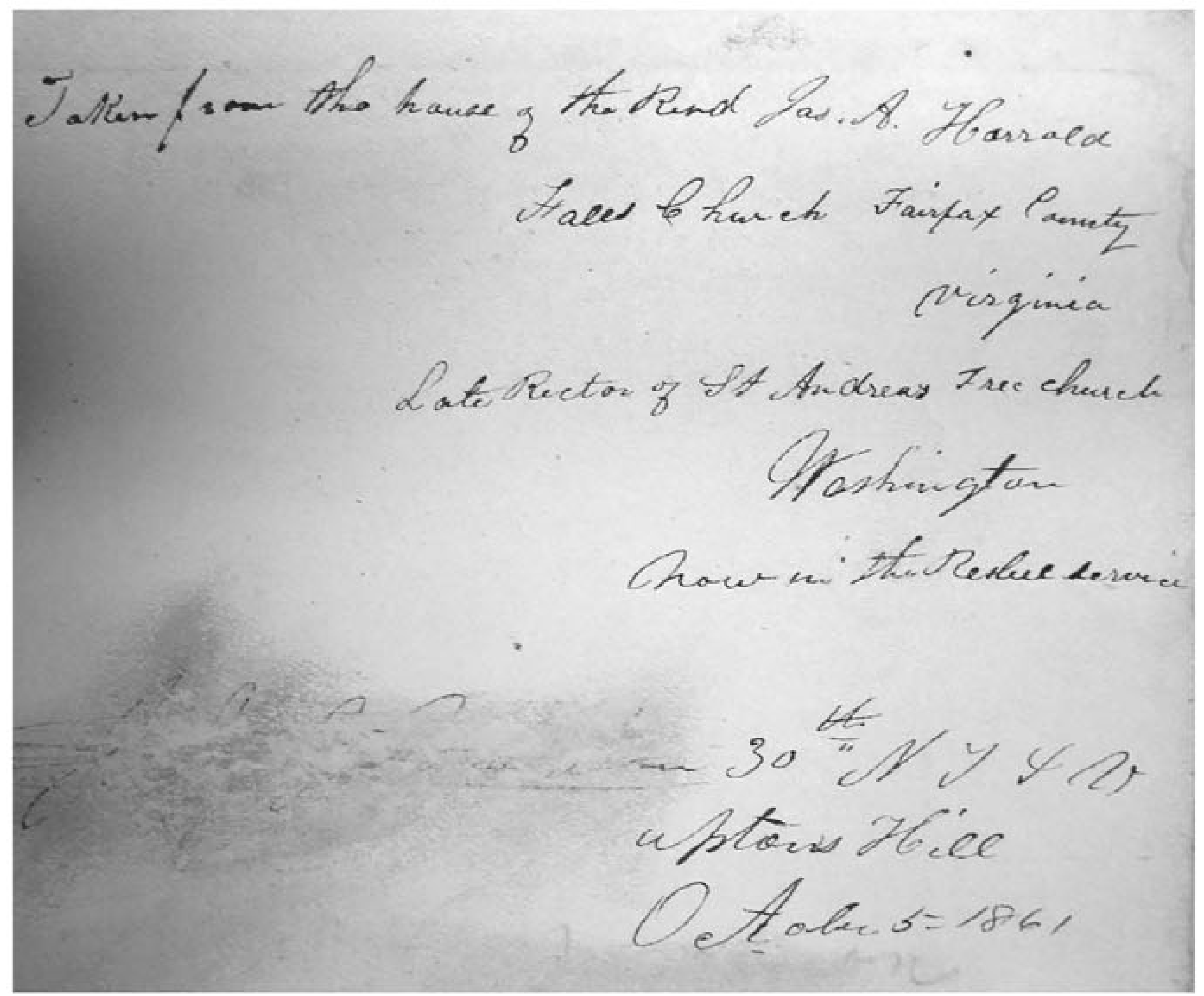

Figure 3. Inscription inside volume 3 of Leopold von Ranke's The History of the Popes (London, 1847-51) showing inscription with history of its looting during the Civil War. Rare Books and Special Collections, Loyola University Chicago, BX955.R33.

project, rather than waiting until the completion of the archive to make it available to the public. A companion website (https://jesuitlibrariesprovenanceproject.com/) provides a portal to the JLPP's Flickr archive and social media feeds (Facebook and Twitter) while also publishing essays on Catholic book and religious history scholarship written by JLPP interns. Researching as they go breaks up the monotony of photographing and metadata generation. Over forty scholarly posts have been uploaded over the first two years of the project. Recent publications address topics as diverse as heretical books, a controversial 1565 English edition of Bede's History of the Church of Englande, a 1473 edition of Pliny's Natural History once owned by a son of King George III, and a richly annotated response to the antebellum Anti-Catholic tract, The Spirit of Popery. ${ }^{13}$ In these posts, students are encouraged to think as much about process as interpretative product and to engage with the material text, not just the ideas contained within it.

Through the Flickr archive and companion website, the JLPP has been able to engage audiences in ways impossible in conventional archives. For example, one 
of the first books recovered was the third volume of an 1847-51 edition of Leopold Von Ranke's Lives of the Popes. The edition itself was unremarkable, but the inscription on the flyleaf caught a student's attention: "Taken from the house of the Rev'd Jas. A. Harrold / Falls Church Fairfax County / Virginia / Late Rector of St. Andrews Free Church / Washington / Now in the Rebel service." A signature beneath had been rubbed out but "30th N.Y.S.V. / Upton's Hill / October 5th, 1861" remained (Figure 3 ). This discovery sparked a conversation among the JLPP team not only about looting and contraband during the American Civil War, but also about the histories hidden within seemingly mundane books. Soon after posting images on Flickr and writing a story for the website, a reader shared entries from the diary of a Union soldier who recorded being at Upton's Hill at that time. In these passages, John Gordon Morrison, a member of the 30th New York State Volunteers, relates going into the house of Harrold, taking this title and several others, and reading them the following Sunday. The reader also shared a photograph of Morrison, making his story come even more alive. Six months later, the great, great granddaughter of Morrison contacted the team, also out of the blue, and provided information about her ancestor and his connection to the Catholic community. More importantly, she placed Morrison in the context of subsequent family history, sharing information about relatives who had gone to Catholic schools and asking for us to reach out to other members of the family without Web access about our find. With each new piece of information, the history of this book was rewritten to include the experiences of those whose lives have been touched by it. ${ }^{14}$

While the primary goal of the JLPP digital archive has been to facilitate new uses of physical collections, the unintended effect has been to inspire undergraduate and graduate students to think in new ways about the history, materiality, and impact of remediation on the texts with which they are working. "After photographing one of the covers of a particular volume of History of the Catholic Church by M. l'Abbé J. E. Darras," wrote undergraduate intern Sarah Muenzer in February 2014, "I saw that the binding of the book was slowly being separated from its spine wide enough so that I could see the original material that bound the book. What I saw made me do a 'double-take': there was text on the interior of the book binding." That discovery led her to ask about the processes of binding and the long history of binding waste, something she had never considered before ${ }^{15}$ Another student noticed that as the cover of an 1807 French-Greek Dictionary faded, it revealed what appeared to be Medieval handwriting. One follower on Flickr suggested it might possibly be 13th-, 14th-, or 15th-century Gothic Latin handwriting. Efforts to decipher the ancient handwriting led to making the acquaintance of Dr. Jeff Rydberg-Cox at the University of Missouri, Kansas City, who is developing a new digital technology for analyzing old texts, and who examined the book. ${ }^{16}$ Finally, an inverted image on the title page of a 1767 edition of the collected works of Horace led intern Michael Albani to research through digital archives and physical rare book collections to discover whether Loyola’s copy represented a unique 
mistake or reflected a larger pattern. ${ }^{17}$ More than just gaining expertise in creating digital images, students have come to acquire, often unexpectedly, a range of specialized knowledge by working so intimately with original and physical objects. Creating a digital archive has required them to confront aspects of the physical collection they had never before considered.

In an age when many still fear that the creation of digital surrogates will efface the preservation of material texts, each of these examples reveals the ways in which the digital and the analog work together to impart new knowledge and to elicit wonder, excitement, and curiosity not only among the JLPP's student interns but also its broader audiences. Even as the digital archive of the JLPP has grown to encompass thousands of images, interns cannot wait to go to the library to work with surviving books. Part of this emanates from their desire to connect physically through the book with the historical subjects that they are studying. They share this impulse with people who visit historic house museums or participate in military reenactments. But these students also exhibit an inherent skepticism with digital surrogates. Once alerted to the presence of the mark of an owner in a text, they want to comb through the material text for other possibly overlooked evidence of ownership or reception. By sharing tales of their research process in their published writings and public lectures, they impart their excitement to, and expand the understanding and knowledge of, their audience. They hope, in turn, to inspire others through their digital efforts to see and know physical objects in new ways.

The Jesuit Libraries Provenance Project set out to harness the digital to help undergraduate and graduate students better understand a physical collection; in turn, the digital archive they created, instead of effacing the physical collection, is helping new audiences discover the material text. The project was informed by a pedagogical approach inspired by the Digital Humanities and Public History that valued collaboration, accommodated a range of engaged learning opportunities, embraced new forms of scholarly publishing, and committed itself to sharing authority. Building a digital archive opened up new avenues to understand and explore the exciting history of early and modern Catholic print and 19th-century Jesuit education through the remediation of physical books. Students have recovered long forgotten histories of ownership, use, and even theft and shared those stories with contemporary readers who did not realize they had an interest in Jesuit-held books. Contrary to the pervasive concern that the digital is lessening the importance of the material object, the JLPP team has created a digital site that encourages participants and followers to rediscover the material text in new and powerful ways.

\section{Notes}

1. The Jesuit Libraries Provenance Project (JLPP), http://jesuitlibrariesprovenanceproject.com/.

2. Crossings and Dwellings: Restored Jesuits, Women Religious, American Experience 1814-2014, Loyola University Museum of Art, July 19-October 19, 2016. www.luc.edu/crossings. 
3. The idea of sharing authority within Public History has its origins in the work of Michael Frisch, A Shared Authority: Essays on the Craft and Meaning of Oral and Public History (Albany, NY: State University of New York Press, 1990).

4. Mark Towsey, "Book Use and Sociability in Lost Libraries of the Eighteenth Century: Towards a Union Catalogue," in Lost Books: Reconstructing the Print World of Pre-Industrial Europe ed. Flavia Bruni and Andrew Pettegree (Leiden: Brill, 2016), chap. 20.

5. City Readers: Digital Historic Collections at the New York Society Library, http://cityreaders.nysoclib.org/; Dissenting Academies Online: Virtual Library System http://vls.english.qmul.ac.uk/; and What Middletown Read, http://www.bsu.edu/libraries/wmr/. For an example of the new kinds of histories that can be written from these digital archives, see Frank Felsenstein and James J. Connolly, What Middletown Read: Print Culture in an American Small City (Amherst, MA: University of Massachusetts Press, 2015).

6. The Jesuits: Cultures, Sciences, and the Arts: 1540-1773, eds. John W. O'Malley, S.J., Gauvin Alexander Bailey, Steven J. Harris, and T. Frank Kennedy, S.J. (Toronto: University of Toronto Press, 1999) and The Jesuits II: Cultures, Sciences, and the Arts, 1540-1773, eds. John W. O'Malley, S.J., Gauvin Alexander Bailey, Steven J. Harris, and T. Frank Kennedy, S.J. (Toronto: University of Toronto Press, 2006). Only about twenty percent of The Cambridge Companion to the Jesuits, ed. Thomas Worcester (Cambridge: Cambridge University Press, 2008) considers the life of the post-suppression order. For two important recent exceptions, see Jesuit Survival and Restoration: A Global History, 1773-1900 ed. Robert A. Maryks and Jonathan Wright (Leiden: Brill, 2015) and John T. McGreevy, American Jesuits and the World: How an Embattled Religious Order Made Modern Catholicism Global (Princeton: Princeton University Press, 2016).

7. Coming out of the concluding conference is a major collection of papers, Crossings and Dwellings: Restored Jesuits, Women Religious, American Experience 1814-2014 eds. Kyle Roberts and Stephen Schloesser (Leiden: Brill, 2017).

8. Gerald McKevitt, "Jesuit Schools in the USA, 1814-c.1870" in The Cambridge Companion to the Jesuits ed. Thomas Worcester, (Cambridge ; New York: Cambridge University Press, 2008), 278-297.

9. Ellen Skerrett, Born in Chicago: A History of Chicago's Jesuit University (Chicago: Loyola Press, 2008).

10. Catalogue of St. Ignatius College, Chicago, Illinois 1877-1878 (Chicago, 1878), 13-17.

11. Jesuit Libraries Project: Recreating Loyola's First Library Catalogue, http://blogs.lib.luc.edu/ archives/. See also Jessica Hagen, "Jesuit Libraries Project: Digital Approaches to Analyzing a Historic Library Catalog," in "The Digital Future of Jesuit Studies," ed. Kyle Roberts, The Catholic Library World 85:4 (June 2015): 248-251.

12. Provenance Project Online, https://provenanceonlineproject.wordpress.com/. A few months after the JLPP launched, Book Traces, created out of the University of Virginia, was begun. http://www.booktraces.org/.

13. See Roman Krasnitsky, "Censor Librorum," in Jesuit Libraries Provenance Project (February 22, 2016) http://jesuitlibrariesprovenanceproject.com/2016/02/22/censor-librorum/; Aaron Kinskey, "The Politics of Bede," in Jesuit Libraries Provenance Project (December 15, 2015) http:// jesuitlibrariesprovenanceproject.com/2015/12/15/the-politics-of-bede/; Evan Thompson, "The Oldest Book in the Collection," in Jesuit Libraries Provenance Project (June 11, 2014) http:// jesuitlibrariesprovenanceproject.com/2014/06/11/the-oldest-book-in-the-collection/; and Michael Albani, "This Book is full of Lies ...." in Jesuit Libraries Provenance Project (October 27, 2015) http://jesuitlibrariesprovenanceproject.com/2015/10/27/this-book-is-full-of-lies-a-stignatius-college-student-vs-the-american-tract-society/.

14. Joshua Arens, "The Mystery of the Looted Book Solved" in Jesuit Libraries Provenance Project (April 13, 2014) http://jesuitlibrariesprovenanceproject.com/2014/04/13/the-mystery-of-thelooted-civil-war-book-solved/ and Evan Thompson, "Jesuit Libraries Provenance Project," in 
"The Digital Future of Jesuit Studies," ed. Kyle Roberts, The Catholic Library World 85:4 (June 2015): 252-255.

15. Sarah Muenzer, "Countdown to Flickr and Our First Case of Binding Waste" in Jesuit Libraries Provenance Project (February 24, 2014) http://jesuitlibrariesprovenanceproject. com/2014/02/24/countdown-to-flickr-and-our-first-case-of-binding-waste/.

16. Joshua Arens, "13th-15th Century Gothic Latin Manuscript Covering Book Found in Cudahy Library-under UV light" in Jesuit Libraries Provenance Project (April 13, 2014) http:// jesuitlibrariesprovenanceproject.com/2014/04/13/13th-century-gothic-latin-manuscriptfound-in-cudahy-library/.

17. Michael Albani, "Horace on His Head: An Error in the St. Ignatius College Library," in Jesuit Libraries Provenance Project (August 17, 2015) http://jesuitlibrariesprovenanceproject. com/2015/08/17/horace-on-his-head-an-error-in-the-st-ignatius-college-library/.

\section{References}

Albani, Michael. 2015. "Horace on His Head: An Error in the St. Ignatius College Library," in Jesuit Libraries Provenance Project August 17 http://jesuitlibrariesprovenanceproject.com/2015/08/17/ horace-on-his-head-an-error-in-the-st-ignatius-college-library/.

Albani, Michael. 2015. "This Book is full of Lies ...," in Jesuit Libraries Provenance Project October 27 http://jesuitlibrariesprovenanceproject.com/2015/10/27/this-book-is-full-of-lies-a-st-ignatiuscollege-student-vs-the-american-tract-society/.

Arens, Joshua. 2014. "The Mystery of the Looted Book Solved" in Jesuit Libraries Provenance Project April 13 http://jesuitlibrariesprovenanceproject.com/2014/04/13/the-mystery-of-the-lootedcivil-war-book-solved/.

Arens, Joshua. 2014. "13th-15th Century Gothic Latin Manuscript Covering Book Found in Cudahy Library - under UV light" in Jesuit Libraries Provenance Project (April 13) http://jesuitlibrariesprovenanceproject.com/2014/04/13/13th-century-gothic-latin-manuscript-found-in-cudahy-library/.

Felsenstein, Frank, and James J. Connolly. 2015. What Middletown Read: Print Culture in an American Small City. Amherst, MA: University of Massachusetts Press.

Frisch, Michael. 1990. A Shared Authority: Essays on the Craft and Meaning of Oral and Public History. Albany: State University of New York Press.

Hagen, Jessica. 2015. "Jesuit Libraries Project: Digital Approaches to Analyzing a Historic Library Catalog," in "The Digital Future of Jesuit Studies," ed. Kyle Roberts, The Catholic Library World 85:4 (June): $248-251$.

Jesuit Libraries Project: Recreating Loyola's First Library Catalogue, http://blogs.lib.luc.edu/archives/.

Kinskey, Aaron. 2015. "The Politics of Bede," in Jesuit Libraries Provenance Project December 15 http://jesuitlibrariesprovenanceproject.com/2015/12/15/the-politics-of-bede/.

Krasnitsky, Roman. 2016. "Censor Librorum," in Jesuit Libraries Provenance Project February 22 http://jesuitlibrariesprovenanceproject.com/2016/02/22/censor-librorum/.

Maryks, Robert A., and Jonathan Wright, edtiors. 2015. Jesuit Survival and Restoration: A Global History, 1773-1900. Leiden: Brill.

McGreevy, John T. 2016. American Jesuits and the World: How an Embattled Religious Order Made Modern Catholicism Global. Princeton: Princeton University Press.

McKevitt, Gerald. 2008. "Jesuit Schools in the USA, 1814-c.1870" in The Cambridge Companion to the Jesuits ed. Thomas Worcester. Cambridge: Cambridge University Press, 278-297.

Muenzer, Sarah. 2014. "Countdown to Flickr and Our First Case of Binding Waste" in Jesuit Libraries Provenance Project February 24 http://jesuitlibrariesprovenanceproject.com/2014/02/24/countdown-to-flickr-and-our-first-case-of-binding-waste/. 
O'Malley, John W., S.J., Gauvin Alexander Bailey, Steven J. Harris, and T. Frank Kennedy, S.J., editors. 1999. The Jesuits: Cultures, Sciences, and the Arts: 1540-1773. Toronto: University of Toronto Press.

O'Malley, John W., S.J., Gauvin Alexander Bailey, Steven J. Harris, and T. Frank Kennedy, S.J., editors. 2006. The Jesuits: Cultures, Sciences, and the Arts: 1540-1773. Toronto: University of Toronto Press.

Provenance Project Online, https://provenanceonlineproject.wordpress.com/.

Roberts, Kyle, and Stephen Schloesser, editors. 2017. Crossings and Dwellings: Restored Jesuits, Women Religious, American Experience 1814-2014. Leiden: Brill.

Skerrett, Ellen. 2008. Born in Chicago: A History of Chicago's Jesuit University. Chicago: Loyola Press.

St. Ignatius College. 1878. Catalogue of St. Ignatius College, Chicago, Illinois 1877-1878. Chicago, 13-17.

Thompson, Evan. 2014. "The Oldest Book in the Collection," in Jesuit Libraries Provenance Project June $11 \mathrm{http} / /$ jesuitlibrariesprovenanceproject.com/2014/06/11/the-oldest-book-in-the-collection/.

Thompson, Evan. 2015. "Jesuit Libraries Provenance Project," in "The Digital Future of Jesuit Studies," ed. Kyle Roberts, The Catholic Library World 85:4 (June): 252-255.

Towsey, Mark. 2016. "Book Use and Sociability in Lost Libraries of the Eighteenth Century: Towards a Union Catalogue," in Lost Books: Reconstructing the Print World of Pre-Industrial Europe ed. Flavia Bruni and Andrew Pettegree. Leiden: Brill, chap. 20. 